\title{
Breast Cancer: Monitoring Response to Neoadjuvant Chemotherapy Using Tc-99m Sestamibi Scintimammography
}

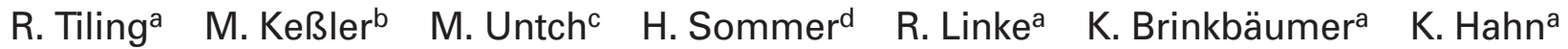 \\ ${ }^{a}$ Klinik für Nuklearmedizin, \\ bInstitut für Klinische Radiologie, \\ ${ }^{c}$ Klinik für Frauenheilkunde, Großhadern, \\ d Universitäts-Frauenklinik, Innenstadt, Ludwig-Maximilians-Universität München, Germany
}

\section{Key Words}

Breast cancer - scintimammography - Tc-99m sestamibi . Neoadjuvant chemotherapy

\begin{abstract}
Summary
Background: Aim of the study was to assess the value of scintimammography using Tc- $99 \mathrm{~m}$ sestamibi in the evaluation of tumor response to neoadjuvant chemotherapy. Material and Methods: Results were calculated for 9 patients undergoing neoadjuvant chemotherapy. Scintimammography using $740 \mathrm{MBq}$ Tc-99m sestamibi was performed before, during and after chemotherapy, and sestamibi uptake was scored visually and semiquantitatively to evaluate tumor response. Results: In the case of complete response $(n=3)$ sestamibi uptake decreased 8 days after beginning neoadjuvant chemotherapy and normalized in the following course. Focal uptake decreased more slowly in patients with partial response ( $n=3$ ), who showed clear, persisting tracer accumulation after therapy. The patients without response $(n=3)$ showed a persisting high tumor activity even after chemotherapy was completed. Conclusions: The preliminary data suggest that in contrast to other imaging modalities scintimammography appears to yield early information regarding tumor response to neoadjuvant chemotherapy.
\end{abstract}

\section{Schlüsselwörter}

Mammakarzinom - Mammaszintigraphie .

Tc-99m Sestamibi · Therapiemonitoring · neoadjuvante Chemotherapie

\section{Zusammenfassung}

Hintergrund: Mit der Mammaszintigraphie steht ein Verfahren zur Diagnostik der Brustdrüsenerkrankungen zur Verfügung, welches sich aufgrund der Limitationen bei der Detektion kleiner Mammakarzinome bislang nicht in der klinischen Routine durchsetzen konnte. Ziel der Arbeit ist es, den Wert des Verfahrens bei der Beurteilung der Wirkung einer neoadjuvanten Chemotherapie von Mammakarzinomen zu überprüfen. Material und Methoden: Dazu wurden bei 9 Patientinnen insgesamt 36 Mammaszintigramme vor, während und nach neoadjuvanter Chemotherapie angefertigt und das Speicherverhalten des eingesetzten Radiopharmazeutikums Tc-99m Sestamibi (740 MBq) mit dem histopathologisch verifizierten Tumoransprechen korreliert. Ergebnisse: Bei den zum Therapiemonitoring durchgeführten Untersuchungen wurde im Falle einer Vollremission $(n=3)$ bereits nach dem 1. Zyklus eine rückläufige Speicherintensität beobachtet, die sich im weiteren Verlauf vollständig normalisierte. Bei partiellem Tumorresponse $(n=3)$ war eine nach 2 Therapiezyklen vergleichsweise geringere Abnahme der Speicherintensität mit Persistenz bis zur Operation vorhanden. Bei fehlendem Tumoransprechen $(\mathrm{n}=3$ ) blieb die Mehrspeicherung im Verlauf konstant hoch. Schlussfolgerungen: Die vorliegenden vorläufigen Daten weisen darauf hin, daß die Mammaszintigraphie geeignet zu sein scheint, bereits frühzeitig das Tumoransprechen auf eine neoadjuvante Chemotherapie zu beurteilen.

\begin{tabular}{ll}
\hline KARGER & ( ) 2003 S. Karger GmbH, Freiburg \\
Fax +497614520714 & Accessible online at: \\
$\begin{array}{l}\text { E-mail Information@Karger.de } \\
\text { www.karger.com }\end{array}$ & www.karger.com/onk
\end{tabular}


Table 1. Visual und semiquantitative sestamibi-uptake before, during and after neoadjuvant chemotherapy related to tumor response

\begin{tabular}{|c|c|c|c|c|c|c|c|c|c|c|c|}
\hline \multirow[t]{2}{*}{ Patient } & \multirow{2}{*}{$\begin{array}{l}\text { Approximate } \\
\text { tumor size, } \\
\mathrm{cm} \\
\text { (mammo- } \\
\text { graphy) }\end{array}$} & \multicolumn{2}{|c|}{$\begin{array}{l}\text { Before } \\
\text { chemotherapy }\end{array}$} & \multicolumn{2}{|c|}{$\begin{array}{l}\text { After 1st cycle } \\
\text { (day 8-10) }\end{array}$} & \multicolumn{2}{|c|}{$\begin{array}{l}\text { After 2nd cycle } \\
\text { (day 26-30) }\end{array}$} & \multicolumn{2}{|c|}{$\begin{array}{l}\text { After } \\
\text { chemotherapy }\end{array}$} & \multirow{2}{*}{$\begin{array}{l}\text { Tumor size, } \\
\mathrm{cm} \\
\text { (histo- } \\
\text { pathology) }\end{array}$} & \multirow[t]{2}{*}{ Response } \\
\hline & & $\mathrm{R}$ & Visual & $\mathrm{R}$ & Visual & $\mathrm{R}$ & Visual & $\mathrm{R}$ & Visual & & \\
\hline 1 & 3 & 2.3 & +++ & 1.9 & ++ & 1.0 & + & 0.9 & 0 & 0 & PCR \\
\hline 2 & 5 & 2.7 & +++ & 2.0 & ++ & 1.0 & + & 1.0 & 0 & 0.3 & CCR \\
\hline 3 & 6 & 1.9 & +++ & 1.7 & +++ & 1.0 & + & 1.0 & 0 & 0.3 & CCR \\
\hline 4 & 4 & 1.8 & +++ & 1.8 & +++ & 1.4 & ++ & 1.2 & + & 1.9 & PR \\
\hline 5 & 5 & 1.5 & ++ & 1.3 & ++ & 1.4 & ++ & 1.2 & + & 2.2 & PR \\
\hline 6 & 4 & 2.5 & +++ & 2.2 & +++ & 1.3 & ++ & 1.1 & + & 1.8 & PR \\
\hline 7 & 7 & 1.8 & +++ & 1.7 & +++ & 1.7 & +++ & 1.5 & +++ & 3.6 & $\mathrm{NC}$ \\
\hline 8 & 5 & 1.6 & +++ & 1.5 & +++ & 1.5 & +++ & 1.5 & +++ & 4.0 & $\mathrm{NC}$ \\
\hline 9 & 6 & 1.6 & +++ & 1.5 & +++ & 1.5 & +++ & 1.6 & +++ & 6 & $\mathrm{NC}$ \\
\hline
\end{tabular}

$\mathrm{R}=$ Tumor : background ratio; visual = visual sestamibi-uptake; $\mathrm{PCR}=$ pathologically complete response $\mathrm{CCR}$ = clinically complete response; $\mathrm{PR}=$ partial response $; \mathrm{NC}=$ no response.

+++ = significant; ++ = moderate; + = slight; 0 = normal.

\section{Introduction}

The first results for scintimammography using Tc-99m sestamibi published between 1994 and 1996 [1-7] were very encouraging with a reported sensitivity of $84-96 \%$ and a specificity of $86-100 \%$. The subsequent publication of two multicenter studies and other targeted investigations, however, led to revision of these optimistic expectations [8-11]. The unsatisfactory delineation of small invasive carcinomas and in-situtumors have shown to be the major limitations of scintimammography. Since the detection of small tumors plays a subordinate role in this particular use, the objective of the present study was to define its role in the evaluation of tumor response in neoadjuvant chemotherapy.

\section{Patients and Methods}

Scintimammographic evaluation of tumor response was performed in patients with confirmed carcinomas undergoing neoadjuvant chemotherapy (epirubicin/paclitaxel). The 9 women underwent 4 scintimammographic examinations each (total 36 examinations) according to the following schedule: prior to therapy, following the first and second therapy cycle (days 8-10 and days 28-30, respectively), and then preoperatively following completion of chemotherapy.

At clinical examination prior to neoadjuvant chemotherapy, all patients exhibited palpable lesions. Previously performed mammography was typical or suspicious for malignancy in all cases. 2 patients additionally underwent magnetic resonance imaging (MRI) with findings rated as definitely malignant. The tumor size estimated clinically or mammographically was larger than $3 \mathrm{~cm}$. Before the women entered the study, malignancy was proven histopatholocically after performing core biopsy.

Prior to scintigraphy, Tc-99m sestamibi (740 MBq) was injected into a cubital vein of the arm contralateral to the breast with the suspected abnormality. 5 min subsequent to injection, planar lateral scintimammograms of the breasts were acquired using a double- or triple-head gamma cam- era. Patients were examined in prone position with raised arms, the acquisition time was $10 \mathrm{~min}$ for each breast.

At visual interpretation of the images, areas of focally increased tracer uptake of any intensity were considered suspicious, as were irregular or confluent areas of increased uptake insofar as they exhibited high intensities and the contralateral breast exhibited normal uptake patterns.

For the evaluation of tumor response to neoadjuvant chemotherapy, uptake patterns of the tumor or breast were assigned to one of four classes based on visual criteria: significant $(+++$, higher than uptake in lung tissue visualized on the same image), moderate $(++$, comparable to uptake in the lung), slight (+, lower than uptake in the lung) or normal ( 0 , no difference to surrounding glandular parenchyma). In addition, semiquantitative evaluation of uptake intensity was performed. This was done at the baseline examination and consisted in imposition of an irregular region of interest (ROI) on the area of increased uptake representing the malignancy and on a reference region of normal tracer uptake in the glandular parenchyma of the ipsilateral breast. The count rates were then compared and a tumor-to-background ratio $(\mathrm{R})$ was calculated. The size of the respective ROIs remained constant during the subsequent examinations in each patient.

Tumor response was classified as follows:

- PCR, pathologically complete remission (no remaining invasive malignant tissue confirmed at histopathology).

- CCR, clinically complete remission (total disappearance of tumor at clinical examination, but histologic evidence of remaining invasive residual tumor).

- PR, partial response (reduction in tumor size by more than one-half of initial size).

- NC, no response (tumor reduction by less than one-half of initial size or further tumor progression).

\section{Results}

All carcinomas in the patient group undergoing neoadjuvant chemotherapy $(n=9)$ were initially characterized by a significantly increased focal tracer uptake. 3 patients showed com- 

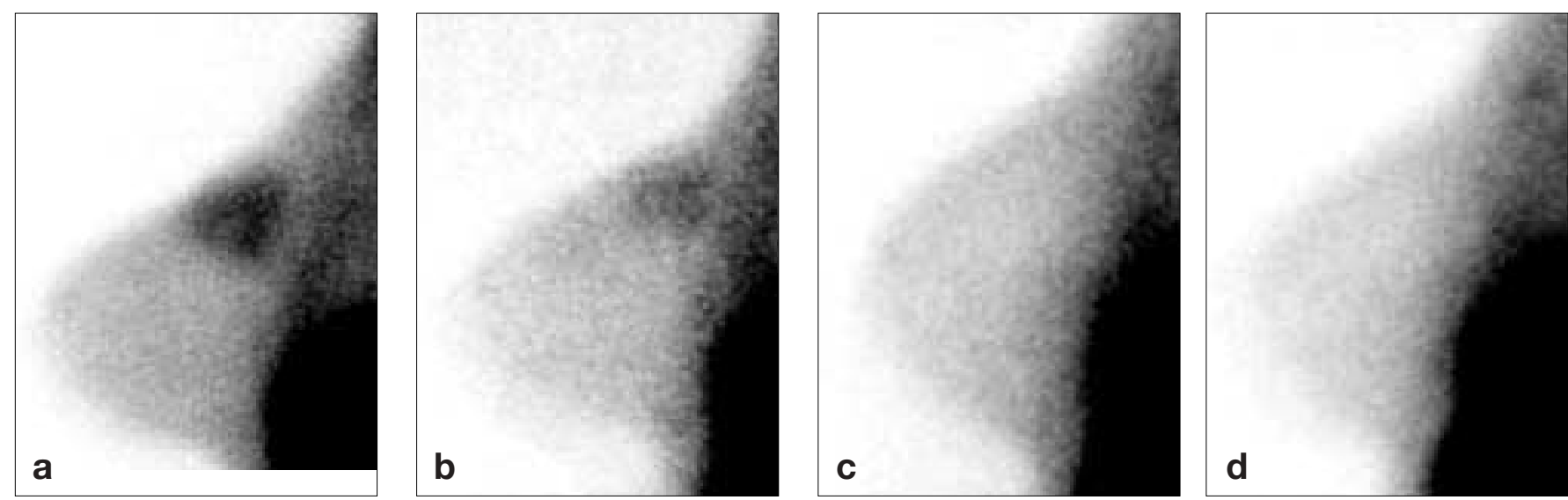

Fig. 1. Invasive breast carcinoma during neoadjuvant chemotherapy, scintimammography (planar lateral views). a) before chemotherapy, $\mathrm{R}=1.9 ; \mathrm{b}$ ) after the 1 st cycle (day 10), $\mathrm{R}=1.7 ; \mathrm{c}$ ) after the 2 nd cycle (day 28), $\mathrm{R}=1.0 ; \mathrm{d}$ ) preoperatively, $\mathrm{R}=1.0 .(\mathrm{R}=$ tumor : background ratio.) Prior to neoadjuvant chemotherapy, there is significant focal sestamibi uptake in the tumor. Following completion of the first chemotherapy cycle, there is significant reduction in uptake intensity, followed by complete normalization during the patient's subsequent clinical course. Histopathology revealed residual invasive tumor $(<3 \mathrm{~mm})$ remaining from the tumor that had measured about $6 \mathrm{~cm}$ prior to chemotherapy; the residual tumor was not visualized at scintimammography. $\mathrm{R}=$ tumor: background ratio

plete tumor remission as a result of neoadjuvant therapy. At scintimammography carcinomas showed visual and semiquantitative evidence of declining tracer uptake after the first therapy cycle (days 8-10). Following the second cycle, semiquantitative values had fallen to normal levels in all cases, although visual interpretation revealed slight focal increased uptake in 2 patients. Following completion of therapy, visual and semiquantitative findings were normal in all cases (table 1, fig. 1). In 2 women with clinically complete remission, residual tumor was revealed at histopathology with diameters up to $3 \mathrm{~mm}$ that escaped detection with scintimammography.

In 3 patients with partial response, scintimammography revealed semiquantitative evidence of decreasing uptake intensity after the first therapy cycle in 2 of 3 cases that did not permit their differentiation from patients with complete response. Following the second therapy cycle and again preoperatively, these patients, unlike those in the group with complete remission, continued to exhibit both visual and semiquantitative evidence of detectable pathologic residual uptake.

The remaining 3 patients with either no response or reduction in tumor size by less than $50 \%$ continued in all examinations, including the preoperative session, to show both semiquantitative and visual evidence of persisting increased sestamibi uptake with at most a very discrete reduction in uptake intensity.

\section{Discussion}

Scintimammography using Tc-99m sestamibi represents a technique that does not depend on morphology but rather visualizes tumor metabolism expressed as a pathologic tracer uptake. It had been postulated that the visualized uptake patterns represent a perfusion-dependent accumulation of the radiopharmaceutical in the tumor, following uptake of the positively charged lipophilic complex by electrostatic interaction with subsequent binding to negatively charged particles in the cytosol and mitochondrial membrane [12]. Experiments have compared the in vitro uptake of Tc-99m sestamibi of normal cell cultures with that of malignant cells [13]. These studies showed that the uptake of the radiopharmaceutical in tumor cells was four times as high as in normal cells. If muscle cells are excluded from the group of normal cells, the uptake of sestamibi was nearly nine times as high as in normal cell cultures.

An indication for scintimammography that has not yet been extensively studied is its role in monitoring neoadjuvant chemotherapy in advanced breast cancer. Investigations by Maini et al. [14] and Mankoff et al. [15] have shown that, in contrast to conventional protocols using clinical examination, ultrasound and mammography, scintimammography is suitable for accurately documenting the response of patients' tumors to therapy. In our study group, response to therapy was demonstrated as early as $8-10$ days following the initiation of chemotherapy in patients ultimately showing complete tumor response as shown by a reduction in tracer uptake. Following completion of the second therapy cycle, tracer uptake patterns had approached normal limits and went on to complete normalization at conclusion of chemotherapy. Residual tumors measuring only a few millimeters, as expected, escaped detection; thus, pre-operative differentiation between clinically and histopathologically complete remission was not possible.

In comparison, patients who ultimately exhibited only partial response to chemotherapy showed a smaller, but still measur- 
able decrease in uptake intensity after the second therapy cycle. Significant residual uptake, however, was visualized at the pre-operative examination.

In non-responders, initial levels of tracer uptake generally remained constant throughout chemotherapy. In individual cases of slight decreases in tracer uptake, a definitive differentiation between partial and non-response to chemotherapy was not possible. This, however, was to be expected due to the definition of the categories partial $(>50 \%$ reduction in tumor size) and non-response ( $<50 \%$ reduction in tumor size).

Another study comparing scintimammography with positron emission tomography (PET) showed that the intensity of Tc$99 \mathrm{~m}$ sestamibi uptake correlated exactly with the degree of glucose metabolism. In fact, both methods returned analogous results documenting tumor response after the second therapy cycle at the latest [16].

Because of the expected increased importance of this therapeutic application in the future, the early evaluation of tumor response to chemotherapy will become an ever greater challenge for diagnostic imaging. If future studies confirm the capabilities of nuclear medical methods in the early detection of response or non-response to chemotherapy, findings of these studies could exert decisive influence on patient management. This application is one in which both conventional imaging techniques and even MRI have significant limitations [17-21]. Feldman et al. [22] showed that nearly $50 \%$ of the patients with clinically complete tumor response (CCR) exhibited macroscopic residual disease, whereas $20 \%$ of the patients with a clinically suggested partial remission (PR) had no macroscopic tumor at surgery. Clinical examination often is unable to differentiate a residual mass representing fibrosis from a mass representing residual tumor. Similar problems were found using mammography to evaluate tumor response. Continuing presence of mammographic density and unchanging microcalcification as a sign for malignancy have shown to be the major reasons for the difficulties of mammography [17-19, 22]. Maini et al. [14] described a sensitivity and specificity of mammography not exceeding 69 and 33\%, respectively. Ultrasound as an adjunct method has similar limitations assessing tumor reponse, since even in case of complete tumor response sonography cannot exclude residual tumor mainly due to fibrosis [23].
Some better results have been reported for contrast-enhanced MRI. Rieber et al. [21] found in the case of tumor response a significant flattening of the Gd-DTPA uptake curve after the first cycle of chemotherapy. After the forth cycle a complete absence of Gd-DTPA uptake was observed. However, these findings led to an underestimation of the extent of tumor in 2 patients and false negative findings in 4 patients. Gilles at al. [24] demonstrated that the contrast behavior after administration of Gd-DTPA corresponds with the amount of residual carcinoma, MRI findings could assess the histopathologic proven disease extent in $83 \%$ in their series.

Early information about the tumor response to neoadjuvant chemotherapy could probably also be achieved using phosphorous-31 magnetic resonance spectroscopy (P-31 MRS). Merchant et al. [25] showed that the different phospholipid profiles correlate with specific histopathologic features like cellular, granulocytic and lymphocytic infiltration, elastosis and necrosis. These histologic features and molecules are known to play important roles in cellular communication, regulation, and processes unique to malignant tissues. The findings demonstrate the specificity of P-31 MRS to distinguish between malignant, benign and noninvolved breast parenchyma and between pathologic subsets of breast cancer [25-27]. For example, phosphomonoester metabolism was shown to be altered in neoplastic tissues relative to the noninvolved tissues, whereas phosphocreatine was elevated in benign tumors. The tissue energy modulus indicated that benign tissue is relatively more aerobic than noninvolved tissue and significantly more aerobic than malignant tissue [26]. Localized P-31 MRS performed sequentially before and during neoadjuvant chemotherapy could probably assess early changes of tumor biochemistry and contribute to monitoring tumor response in this way.

In conclusion, the limitations of scintimammography in detecting small tumors play a subordinate role in the use of this method for the evaluation of signs of response of carcinomas to neoadjuvant chemotherapy. The findings of the present study suggest that this may be an important new indication for scintimammography. However, with respect to the very limited number of patients enrolled in this study, further examinations will be necessary to define the role of this technique in the future.

\section{References}

1 Khalkhali I, Mena I, Diggles L: Review of imaging techniques for the diagnosis of breast cancer: A new role of prone scintimammography using technetium-99m sestamibi. Eur J Nucl Med 1994;21: 357-362.

2 Kao CH, Wang SJ, Liu TJ: The use of technetium$99 \mathrm{~m}$ methoxyisobutylisonitrile breast scintigraphy to evaluate palpable breast masses. Eur J Nucl Med 1994;21:432-436.
3 Burak Z, Argon M, Memis A, Erdem S, Balkan Z, Duman Y, Ustun EE, Erhan Y, Ozkilic H: Evaluation of palpable breast masses with 99Tcm-MIBI: A comparative study with mammography and ultrasonography. Nucl Med Commun 1994;15:604612.

4 Khalkhali I, Cutrone J, Mena I, Diggles L, Venegas R, Vargas H, Jackson B, Klein S: Technetium-99msestamibi scintimammography of breast lesions: Clinical and pathological follow-up. J Nucl Med 1995;36:1784-1789.
5 Piccolo S, Lastoria S, Mainolfi C, Muto P, Bazzicalupo L, Salvatore M: Technetium-99m-methylene diphosphonate scintimammography to image primary breast cancer. J Nucl Med 1995;36:718724.

6 Taillefer R, Robidoux A, Lambert R, Turpin S, Laperriere J: Technetium-99m-sestamibi prone scintimammography to detect primary breast cancer and axillary lymph node involvement. J Nucl Med 1995;36:1758-1765. 
7 Khalkhali I, Cutrone J, Mena IG, Diggles LE, Venegas RJ, Vargas HI, Jackson BL, Khalkhali S, Moss JF, Klein SR: Scintimammography: The complementary role of Tc-99m sestamibi prone breast imaging for the diagnosis of breast carcinoma. Radiology 1995;196:421-426.

8 Tiling R, Khalkhali I, Sommer H, Moser R, Meyer G, Willemsen F, Pfluger T, Tatsch K, Hahn K: Role of Technetium-99m sestamibi scintimammography and contrast enhanced magnetic resonance imaging for the evaluation of indeterminate mammograms. Eur J Nucl Med 1997;24:1221-1229.

9 Palmedo H, Biersack HJ, Lastoria S, Maublant J, Prats E, Stegner HE, Bourgeois P, Hustinx R, Hilson AJ, Bischof-Delaloye A: Scintimammography with Technetium-99m methoxyisobutylisonitrile: Results of a prospective European multicentre trial. Eur J Nucl Med 1998;25:375-385.

10 Tiling R, Khalkhali I, Sommer H, Linke R, Moser R, Willemsen F, Pfluger T, Tatsch K, Hahn K: Limited value of scintimammography and contrast-enhanced MRI in the evaluation of microcalcification detected by mammography. Nucl Med Commun 1998;19:55-62.

11 Khalkhali I, Villanueva-Meyer J, Edell SL, Connolly JL, Schnitt SJ, Baum JK, Houlihan MJ, Jenkins RM, Haber SB: Diagnostic accuracy of 99mTc-sestamibi breast imaging: Multicenter trial results. Nucl Med 2000;41:1973-1979.

12 Carvalho PA, Chiu ML, Kronauge JF, Kawamura M, Jones AG, Holman BL, Piwnica-Worms D: Subcellular distribution and analysis of Tc-99m MIBI in isolated perfused rat hearts. J Nucl Med 1992;33: 1516-1521.

13 Maublant JC, Zhang Z, Rapp M, Ollier M, Michelot J, Veyre A: In vitro uptake of Tc-99m texoboroxime in carcinoma cell lines and normal cell lines: Comparison with Tc-99m sestamibi and thallium-201. J Nucl Med 1993;34:1949-1952.

14 Maini CL, Tofani A, Sciuto R, Semprebene A, Cavaliere R, Mottolese M, Benevolo M, Ferranti F, Grandinetti ML, Vici P, Lopez M, Botti C: Technetium99m-MIBI scintigraphy in the assessment of neoadjuvant chemotherapy in breast carcinoma. J Nucl Med 1997:38:1546-1551.

15 Mankoff DA, Dunnwald LK, Gralow JR, Ellis GK, Drucker MJ, Livingston RB: Monitoring the response of patients with locally advanced breast carcinoma to neoadjuvant chemotherapy using [Technetium 99m]-sestamibi scintimammography. Cancer 1999;85:2410-2423.

16 Tiling R, Linke R, Untch M, Richter A, Fieber S, Brinkbaumer K, Tatsch K, Hahn K: 18F-FDG PET and 99mTc-sestamibi scintimammography for monitoring breast cancer response to neoadjuvant chemotherapy: A comparative study. Eur J Nucl Med 2001;28:711-720.

17 Segel MC, Paulus DD, Hortobagyi GN: Advanced primary breast cancer: Assessment at mammography of response to induction chemotherapy. Radiology 1988;169:49-54.

18 Moscovic EC, Mansi JL, King DM, Murch CR, Smith IE: Mammography in the assessment of response to medical treatment of large primary breast cancer. Clin Radiol 1993;47:339-344.

19 Vinnicombe SJ, MacVicar AD, Guy RL, Sloane JP, Powles TJ, Knee G, Husband JE: Primary breast cancer: Mammographic changes after neoadjuvant chemotherapy, with pathologic correlation. Radiology 1996;198:333-340.

20 Knopp MV, Brix G, Junkermann HJ, Sinn HP: MR mammography with pharmakokinetic mapping for monitoring of breast cancer treatment during neoadjuvant therapy. Magn Reson Imaging Clin N Am 1994;2:633-658.

21 Rieber A, Zeitler H, Rosenthal H, Gorich J, Kreienberg R, Brambs HJ, Tomczak R: MRI of breast cancer: Influence of chemotherapy on sensitivity. Br J Radio 1997;70:452-458.

22 Feldman LD, Hortobagyi GN, Buzdar AU, Ames FC, Blumenschein GR: Pathological assessment of response to induction chemotherapy in breast cancer. Can cer Res 1986;46:2578-2581.

23 Chollet P, Charrier S, Brain E, Cure H, van Praagh I, Feillel V, de Latour M, Dauplat J, Misset JL, Ferriere JP: Clinical and pathological response to primary chemotherapy in operable breast cancer. Cancer 1997;33:862-866.

24 Gilles R, Guinebretiere J, Toussaint C, Spielman M, Rietjens M, Petit JY, Contesso G, Masselot J, Vanel D: Locally advanced breast cancer: Contrast enhanced subtraction MR imaging of response to preoperative chemotherapy. Radiology 1994;191: 633-638.

25 Merchant TE, Kasimos JN, Vroom T, de Bree E, Iwata JL, de Graaf PW, Glonek T: Malignant breast tumor phospholipid profiles using (31)P magnetic resonance. Cancer Lett 2002;176:159- 167.

26 Merchant TE, Gierke LW, Meneses P, Glonek T: 31P magnetic resonance spectroscopic profiles of neoplastic human breast tissues. Cancer Res 1988; 48:5112-5118.

27 Merchant TE, Meneses P, Gierke LW, Den Otter W, Glonek T: 31P magnetic resonance phospholipid profiles of neoplastic human breast tissues. Br J Cancer 1991;63:693-698. 